3-1-1996

\title{
Lethal limits and sublethal effects of hypoxia on the amphipod Gammarus pseudolimnaeus
}

\author{
W. Wyatt Hoback \\ MSU Graduate Student \\ M. Christopher Barnhart \\ Missouri State University
}

Follow this and additional works at: https://bearworks.missouristate.edu/articles-cnas

\section{Recommended Citation}

Hoback, W. Wyatt, and M. Christopher Barnhart. "Lethal limits and sublethal effects of hypoxia on the amphipod Gammarus pseudolimnaeus." Journal of the North American Benthological Society 15, no. 1 (1996): 117-126.

This article or document was made available through BearWorks, the institutional repository of Missouri State University. The work contained in it may be protected by copyright and require permission of the copyright holder for reuse or redistribution.

For more information, please contact BearWorks@library.missouristate.edu. 


\section{Lethal Limits and Sublethal Effects of Hypoxia on the Amphipod Gammarus pseudolimnaeus}

Article in Journal of the North American Benthological Society · March 1996 DOI: $10.2307 / 1467437$ 


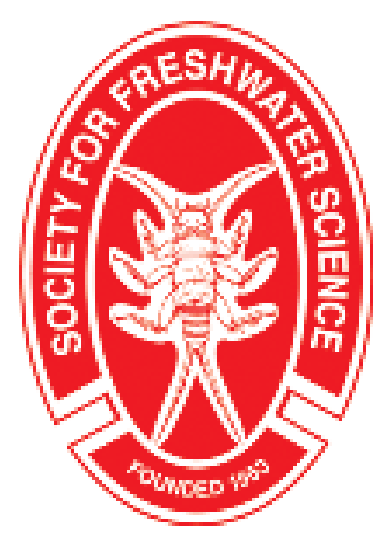

Lethal Limits and Sublethal Effects of Hypoxia on the Amphipod Gammarus pseudolimnaeus Author(s): W. Wyatt Hoback and M. Christopher Barnhart

Source: Journal of the North American Benthological Society, Vol. 15, No. 1 (Mar., 1996), pp. 117-126

Published by: Society for Freshwater Science

Stable URL: http://www.jstor.org/stable/1467437

Accessed: 16/01/2015 18:59

Your use of the JSTOR archive indicates your acceptance of the Terms \& Conditions of Use, available at http://www.jstor.org/page/info/about/policies/terms.jsp

JSTOR is a not-for-profit service that helps scholars, researchers, and students discover, use, and build upon a wide range of content in a trusted digital archive. We use information technology and tools to increase productivity and facilitate new forms of scholarship. For more information about JSTOR, please contact support@jstor.org. 


\title{
Lethal limits and sublethal effects of hypoxia on the amphipod Gammarus pseudolimnaeus
}

\author{
W. WYATT HOBACK ${ }^{1}$ AND M. CHRISTOPHER BARNHART ${ }^{2}$ \\ Department of Biology, Southwest Missouri State University, 901 S. National, \\ Springfield, Missouri 65804 USA
}

\begin{abstract}
The amphipod Gammarus pseudolimnaeus is an important prey species for trout in certain tailwater fisheries below hydropower dams. The effects of low dissolved oxygen (DO) on this species were investigated in laboratory experiments. The duration of survival in anoxia and in lethally low DO concentrations differed among adult female, adult male, and juvenile individuals. Adult females were the group most sensitive to both anoxia and hypoxia; for example, $\mathrm{LC}_{50}$ in hypoxia was 2.00 , 1.28 , and $1.05 \mathrm{mg} / \mathrm{L}$, respectively, for females, males and juveniles $\left(48 \mathrm{~h}, 15^{\circ} \mathrm{C}\right)$. Juveniles were generally less sensitive to hypoxia but more sensitive to anoxia than were adult males. $\mathrm{LC}_{50}$ increased with increasing temperature but changed little with duration of exposure after $24 \mathrm{~h}$. The rate of oxygen consumption was a hyperbolic function of DO without a distinct critical level; oxygen consumption was depressed $10 \%$ at $5.7 \mathrm{mg} / \mathrm{L}$ and $50 \%$ at $1.3 \mathrm{mg} / \mathrm{L}\left(15^{\circ} \mathrm{C}\right)$. Hypoxia induced the separation of amplexing pairs at $2 \mathrm{ppm}$ and inhibited the reunion of separated pairs at $5 \mathrm{ppm}\left(15^{\circ} \mathrm{C}\right)$. Current US government (US Environmental Protection Agency) criteria for DO appear to be sufficient for protection of this species, but these criteria may often not be met below hypolimnetic-release hydropower dams.
\end{abstract}

Key words: amphipod, anoxia, hypoxia, Gammarus, LC $_{50}$, respiration, mate-guarding.

Gammarus pseudolimnaeus is a freshwater amphipod common in springs and cool-water streams of the upper Mississippi and Great Lakes drainages (Bousfield 1958, Pennak 1989). In appropriate conditions this species is highly productive (Waters and Hokenstrom 1980, Marchant and Hynes 1981) and is an important food for fishes (Hanson and Waters 1974). The present study was prompted by concern regarding the effects of seasonal hypoxia (low dissolved oxygen) on G. pseudolimnaeus in the tailwaters of Table Rock Dam, a hydropower facility in southwestern Missouri. Gammarus pseudolimnaeus was introduced to the system in 1961 to provide food for stocked trout in the cool tailwaters below the dam. Thermal stratification of the upstream reservoir results in severe hypoxia in the hypolimnion during the summer and fall. To protect the trout fishery, the dissolved oxygen content (DO) of water released from the dam is usually prevented from falling below 4 ppm by air entrainment and liquid oxygen injection (Weithman and Haas 1984, Hoback 1995). However, little information exists to show what effect this level of hypoxia may have upon

${ }^{1}$ Present address: School of Biological Sciences, Manter Hall, University of Nebraska, Lincoln, Nebraska 68588 USA

${ }^{2}$ To whom correspondence should be addressed the amphipods which form the food base for the fishery.

Gammarid amphipods are generally characterized as being intolerant of hypoxia and they may be useful indicators of water quality (Poulton and Pascoe 1990, Meijering 1991). However, few studies have quantified the hypoxia tolerance of amphipods in controlled conditions (Sprague 1963, Gaufin 1973, Nebeker et al. 1992). Death of the test organism has been used as the end point in most bioassay procedures to establish water quality criteria for dissolved oxygen (e.g., Gaufin 1973, Nebeker et al. 1992). However, sublethal responses may be more useful in assessing effects on populations (Poulton and Pascoe 1990).

Quantification of hypoxia tolerance is desirable, both to facilitate use of these organisms as bioindicators and to establish water quality standards that are consistent with their requirements. The hypoxia tolerance of age and sex classes is also of interest. Size differences may affect tolerance of hypoxia because of allometric effects of size upon surface/volume ratio and metabolic rate (Schmidt-Nielsen 1984). In Gammarus, size differs not only among juveniles and adults, but also between sexes, with females generally being smaller than males (Conlan 1991). Few studies have attempted to compare 
the sensitivity of adult and juvenile or male and female invertebrates to hypoxic stress (Sprague 1963, Sutcliffe 1984). In the present study we compared the lethal levels of hypoxia among adult male, adult female, and juvenile G. pseudolimnaeus and quantified the effects of hypoxia on respiration and on precopulatory mateguarding behavior (amplexus).

\section{Methods}

Gammarus pseudolimnaeus were collected by kickscreen in a small stream at Shepherd of the Hills Fish Hatchery, below Table Rock Dam, Taney County, Missouri $\left(36^{\circ} 39.5^{\prime} \mathrm{N}, 93^{\circ} 7.5^{\prime} \mathrm{W}\right)$. Water in this stream originates from the dam and has similar temperature to that in the tailwaters. DO in the stream is uniformly high as a result of aeration at the hatchery, so that test animals were not previously acclimated to low DO. Amphipods were identified using keys by Bousfield (1958). Animals were taken to the lab in an insulated, aerated container and transferred into aerated aquaria kept at $12^{\circ} \mathrm{C}$. A sheet of coarse polyester mesh (Aquatic Ecosystems PF-2) was supplied as a substrate. The aquaria were continually lit with Gro-lux ${ }^{\mathrm{TM}}$ lights to encourage algal growth for food and to minimize possible effects of circadian rhythms. Animals were held for less than $1 \mathrm{wk}$ before use in experiments.

We distinguished 3 categories of individuals in experiments: adult male, adult female and juvenile. Adult male and female amphipods were identified by selecting pairs in amplexus. Pairs were briefly emersed until they separated and then the smaller females were isolated from the males. Juvenile amphipods were selected based on size. Individual wet body mass $(\mathrm{mg}$ ) for the 3 categories was as follows: adult male $=61 \pm$ 15.5 , adult female $=41 \pm 3.1$, juvenile $=12 \pm$ 0.5 (mean $\pm 1 \mathrm{SD}, n=90$ individuals each).

\section{Anoxia}

The time to $50 \%$ mortality $\left(\mathrm{LT}_{50}\right)$ in anoxia was determined by exposing 30 individuals ( 3 groups of 10 animals each) at each of 3 temperatures; 10,15 , and $20^{\circ} \mathrm{C}$. Equivalent experiments were performed with adult male, female, and juvenile individuals (270 animals total). Test chambers consisted of 250-mL glass Erlenmeyer flasks sealed by a rubber stopper fitted with 2 stopcocks, 1 of which led to an airstone within the flask. Animals were placed in each chamber with $100 \mathrm{~mL}$ of deoxygenated water. The chambers were closed, sealed with parafilm, and purged by bubbling with purified nitrogen gas for $3 \mathrm{~min}$ before closing the stopcocks. DO was checked with an oxygen electrode (Orion Model 820) after the tests and was found to be less than $0.2 \mathrm{ppm}$ in each case.

The chambers were placed in temperaturecontrol cabinets. The number of survivors was recorded every $30 \mathrm{~min}$. Mortality was judged by careful visual examination of each individual. Individuals were scored as dead if pleopods did not move, posture was extended, and shaking of the chamber caused no response. In preliminary tests, such individuals did not recover when returned to normoxia. Individuals that exhibited pleopod movement did recover when returned to normoxia. $\mathrm{LT}_{50}$ (time to $50 \%$ mortality) and $95 \%$ confidence intervals of $\mathrm{LT}_{50}$ were calculated using Toxstat 3.4 (Western Ecosystems Technology, Inc., Cheyenne, Wyoming).

\section{Hypoxia}

The concentrations of dissolved oxygen resulting in $50 \%$ mortality $\left(\mathrm{LC}_{50}\right)$ at 24,48 , and 72 $h$ of exposure were determined by exposing animals to controlled levels of DO in a flowthrough system. A gas-stripping column and reoxygenation ladder were used to supply water with desired levels of DO (Barnhart 1995). Six water manifolds delivered water to 18 flowthrough chambers ( 3 at each level of DO). The chambers ( $200 \mathrm{~mL}$ volume) were suspended in a 110-L temperature-controlled water bath. No access to air was possible within the chambers. Flow through each chamber was monitored by flowmeters and was approximately $25 \mathrm{~mL} / \mathrm{min}$.

In each experiment, groups consisting of 3 males, 3 females, or 3 juveniles were exposed to each of 6 levels of DO ranging from 1\% to $85 \%$ air saturation at 10,15 , or $20^{\circ} \mathrm{C}$. The chambers were checked and survival was recorded daily for $3 \mathrm{~d}$. DO was recorded daily by an oxygen electrode in the lines delivering water to the chambers. Food was not provided during the exposures (we have observed that G. pseudolimnaeus survive total starvation, including isolation from feces, for several weeks). The experiment was repeated 5 times for a total of 15 males, 15 females, and 15 juveniles tested at 
each of 6 levels of DO at each of 3 temperatures (810 animals total).

Effects of DO and sex/age class on survivorship were tested with 2-way ANOVA at each combination of temperature and exposure time. Tukey's test was used to test pairwise differences among group means and to determine the highest adverse-effect DO (the highest DO in which survivorship was significantly lower than in controls). Spearman-Karber estimates of $\mathrm{LC}_{50}$ (oxygen concentration causing $50 \%$ mortality) were calculated using Toxstat 3.4. The Spearman-Karber estimate assumes that no deaths occur in the control and that effect increases with magnitude of exposure. The data met both assumptions.

\section{Respirometry}

Rate of oxygen consumption $\left(\mathrm{MO}_{2}\right)$ of individual amphipods was measured using closedchamber respirometry. Three cylindrical glass chambers ( $15 \mathrm{~mL}$ volume) were water-jacketed within an acrylic box for temperature control $\left( \pm 0.1^{\circ} \mathrm{C}\right)$. We used 2 chambers for measurement, the 3rd for electrode calibration. Chambers were continuously stirred by magnet bars isolated from the animals by a screen partition, and a piece of coarse polyester mesh was provided to which the animals could cling (convection and substrate minimize the activity-related or "stress"-related component of metabolism [Rees 1972, Wallace et al. 1975]). Nylon plugs closed the chambers and displaced internal volume to $5 \mathrm{~mL}$. Oxygen pressure $\left(\mathrm{PO}_{2}\right)$ within each chamber was recorded at 1-min intervals with an oxygen electrode (Micro-Electrodes model MI 730-A), dual-channel oxygen meter (Cameron Instruments model OM 210), Workmate A/D board (Strawberry Tree Inc.), and a microcomputer.

Male and female individuals were obtained by separating amplexing pairs. Individuals were held without food for 10-15 h before measurements to standardize nutritional state and decrease feces production. Prior to each experiment, the chambers were washed with $70 \%$ ethanol to minimize bacterial oxygen consumption. Measured background oxygen consumption was negligible. Oxygen electrodes were calibrated in stirred, air-equilibrated water. The chambers were filled with conditioned tap water and bubbled briefly with oxygen to raise $\mathrm{PO}_{2}$ to about 175 Torr (air saturation $=150$ Torr). We added 1 animal to each chamber and closed the chambers. Measurements continued until $\mathrm{PO}_{2}$ dropped below 10 Torr $(1-4 \mathrm{~h})$. The electrode calibration was then checked, the chambers were washed and refilled, and a 2nd and occasionally 3 rd respiration series was recorded from each individual. We tested 52 individuals. After the last run, the animals were removed from the chambers, blotted, and weighed to the nearest $0.1 \mathrm{mg}$ (wet mass), then dried for $48 \mathrm{~h}$ at $90^{\circ} \mathrm{C}$ and reweighed (dry mass).

Closed chamber respirometry is more sensitive than open-flow methods, but has the disadvantage that water quality changes during measurements (Kaufmann et al. 1989). We used closed chambers for sensitivity and because the decline in $\mathrm{PO}_{2}$ over time allowed $\mathrm{MO}_{2}$ to be measured as a function of $\mathrm{PO}_{2}$. Accumulation of carbon dioxide and other metabolites in the chambers was minimized by changing water between runs. $\mathrm{MO}_{2}$ was calculated from change in the 3-min running average of chamber $\mathrm{O}_{2}$ content at 15-min intervals. Multiple runs on an individual were averaged. Analysis of covariance (ANCOVA, GLM) was used to test effects of temperature, sex, and mass on $\dot{\mathrm{MO}}_{2}$ at 150 Torr (Minitab, Inc. Version 8.0). The relationship between $\mathrm{MO}_{2}$ and $\mathrm{PO}_{2}$ was quantified by linear regression of the ratio $\mathrm{PO}_{2} / \mathrm{MO}_{2}$ on $\mathrm{PO}_{2}$, and the ratio intercept/slope was used to quantify the dependence of $\mathrm{MO}_{2}$ on $\mathrm{PO}_{2}$ (Tang 1933). These regressions can also be used as predictive equations relating $\mathrm{PO}_{2}$ and $\mathrm{MO}_{2}$.

\section{Mate-guarding behavior}

The effect of hypoxia on mate-guarding behavior (amplexus) was tested in an acrylic chamber $(25 \mathrm{~cm} \times 10 \mathrm{~cm} \times 5 \mathrm{~cm})$ divided into 5 cells by screen partitions. Each of the 5 cells was further divided in half by removable partitions. Water was circulated through the chamber from a 2-L reservoir which was bubbled with mixtures of oxygen and nitrogen delivered by a gas-mixing system (Matheson Multiple Dyna-Blender model 8284 and Matheson massflow transducers). Temperature $\left(15^{\circ} \mathrm{C}\right)$ and $\mathrm{DO}$ were monitored continuously. Amplexing pairs were separated into adjacent halves of each partitioned cell. After $10 \mathrm{~min}$, the partitions were removed so that the individuals of each pair could interact. The number of reunited pairs 
TABLE 1. Time (h) to $50 \%$ mortality in anoxia for male, female, and juvenile Gammarus pseudolimnaeus at 3 temperatures. Values are Spearman-Karber estimates of $\mathrm{LT}_{50}(95 \%$ confidence interval). Shared superscripts indicate overlapping confidence intervals. The sequence of superscripts $(a-d)$ indicates long-short values of $\mathrm{LT}_{50}$.

\begin{tabular}{lccc}
\hline \hline & $10^{\circ} \mathrm{C}$ & $15^{\circ} \mathrm{C}$ & $20^{\circ} \mathrm{C}$ \\
\hline Male & $3.53(3.17-3.91)^{\mathrm{a}}$ & $2.87(2.56-3.18)^{\mathrm{a}}$ & $1.57(1.44-1.69)^{\mathrm{c}}$ \\
Female & $2.17(1.86-2.48)^{\mathrm{b}}$ & $1.87(1.71-2.03)^{\mathrm{b}}$ & $0.88(0.76-1.00)^{\mathrm{d}}$ \\
Juvenile & $3.23(2.96-3.58)^{\mathrm{a}}$ & $1.42(1.27-1.56)^{\mathrm{c}}$ & $1.07(0.96-1.17)^{\mathrm{d}}$ \\
\hline
\end{tabular}

was recorded $15 \mathrm{~min}$ later. This procedure was repeated with new animals 10 times at each level of DO (50 pairs total at each level). DO levels tested were $10,7,5,4,3$, and $2 \mathrm{ppm}$. The percent of pairs that reunited was transformed (arc-sine square-root) for normality (Zar 1984). Results were compared using one-way ANOVA and Tukey tests (Minitab 8.0).

In a second study, groups of paired amphipods were exposed to hypoxia in the flowthrough system described above. The levels of DO tested were $8.7 \mathrm{ppm}, 5.5 \mathrm{ppm}, 4.4 \mathrm{ppm}, 3.0$ $\mathrm{ppm}, 2.7 \mathrm{ppm}$, and $2.0 \mathrm{ppm}$. For each treatment, 3 groups of 3 pairs each were tested at each of 6 levels of hypoxia. The number of pairs was recorded daily for $3 \mathrm{~d}$. Where mortality occurred, the percent paired was calculated based upon the possible number of pairs remaining. This procedure was repeated 4 times with new animals for a total of 36 possible pairs at each level of hypoxia. Normalized (arc-sine squareroot) data were compared by 1-way ANOVA and Tukey pairwise comparisons.

\section{Results}

\section{Anoxia}

Survivorship in anoxia varied with temperature and age/sex class (Table 1). Non-overlapping confidence intervals indicate that $\mathrm{LT}_{50}$ of females was significantly shorter than that of males at all temperatures (Table 1). Juveniles died faster than males at 15 and $20^{\circ} \mathrm{C}$, and faster than females at $15^{\circ} \mathrm{C}$. All groups died faster at higher temperatures; $\mathrm{LT}_{50}$ at $10^{\circ} \mathrm{C}$ was $2.25 \times$, $2.47 \times$, and $3.02 \times$ longer than at $20^{\circ} \mathrm{C}$ for males, females, and juveniles, respectively.

\section{Hypoxia}

Females were significantly less tolerant of hypoxia than males $(p<0.05)$ at $10^{\circ} \mathrm{C}$ and $15^{\circ} \mathrm{C}$ but not at $20^{\circ} \mathrm{C}$, where female and male survivorship did not differ significantly. Both $\mathrm{LC}_{50}$ and highest-adverse-effect level of DO were generally highest in adult females (Tables 2,3 ). For example, at $15^{\circ} \mathrm{C}$ and $48 \mathrm{~h}, \mathrm{LC}_{50}$ of females was $1.9 \times$ that of juveniles and $1.56 \times$ that of males. Juveniles were more tolerant of hypoxia than were female adults in every category of time and temperature, and more tolerant than adult males in 8 of 9 comparisons (Table 2). LC $_{50}$ increased with increased temperature: $48-\mathrm{h} \mathrm{LC}_{50}$ values at $20^{\circ} \mathrm{C}$ were $1.9 \times, 2.4 \times$, and $2.3 \times$ higher than at $10^{\circ} \mathrm{C}$ for females, males, and juveniles, respectively. $\mathrm{LC}_{50}$ increased little with increased duration of exposure. At $15^{\circ} \mathrm{C}, 72 \mathrm{~h} \mathrm{LC}_{50}$ was $1.2 \times, 1.1 \times$, and $1.4 \times$ that at $24 \mathrm{~h}$ for females, males, and juveniles, respectively (Table 2).

\section{Respiration}

The allometric effect of body mass on $\mathrm{MO}_{2}$ was determined by regression of $\log \mathrm{MO}_{2}(\mathrm{mg} /$ $\mathrm{h}$ ) on log body mass (mg) (Schmidt-Nielsen 1984). With temperature as covariate, ANCOVA yielded a mass correction coefficient of 0.55 (calculated from all $52 \mathrm{MO}_{2}$ measurements at 150 Torr excepting 3 outliers identified by Minitab [2 at $10^{\circ}$ and 1 at $15^{\circ} \mathrm{C}$ ]). For subsequent analysis, the effect of body mass was removed by dividing $\mathrm{MO}_{2}$ by body mass ${ }^{0.55}$.

$\mathrm{MO}_{2}$ was a hyperbolic function of $\mathrm{PO}_{2}$; the slope of the dependence was steeper at lower DO (Fig. 1). Linear regression of $\mathrm{MO}_{2} / \mathrm{PO}_{2}$ vs. $\mathrm{PO}_{2}$ produced excellent fits $\left(R^{2}>0.99\right)$ and these regressions are presented as predictive equations (Table 4). Comparisons of the intercept/slope ratio (Tang 1993, Bayne 1971) did not reveal significant differences in the oxygen-dependence of respiration between sexes or temperatures. $\mathrm{MO}_{2}$ increased with temperature (ANCOVA $p<0.0001$ ). The DO at which $\mathrm{MO}_{2}$ was reduced by half remained relatively con- 
TABLE 2. Concentrations of dissolved oxygen (ppm) resulting in $50 \%$ mortality of male, female, and juvenile Gammarus pseudolimnaeus over 3 exposure periods. Values are Spearman-Karber estimates of $\mathrm{LC}_{50}(95 \%$ confidence interval). Shared superscripts indicate overlapping confidence intervals. The sequence of superscripts (a$\mathrm{g}$ ) indicates low-high values of $\mathrm{LC}_{50}$.

\begin{tabular}{lccc}
\hline \hline & \multicolumn{1}{c}{$24 \mathrm{~h}$} & $48 \mathrm{~h}$ & $72 \mathrm{~h}$ \\
\hline $10^{\circ} \mathrm{C}$ & & & \\
$\quad$ Female & $1.41(1.25-1.57)^{\mathrm{d}}$ & $1.66(1.46-1.86)^{\mathrm{d}, \mathrm{e}}$ & $1.77(1.58-1.96)^{\mathrm{e}}$ \\
Male & $0.91(0.74-1.08)^{\mathrm{b}, \mathrm{c}}$ & $1.22(1.04-1.40)^{\mathrm{c}, \mathrm{d}}$ & $1.45(1.30-1.60)^{\mathrm{d}, \mathrm{e}}$ \\
Juvenile & $0.35(0.18-0.52)^{\mathrm{a}}$ & $0.78(0.59-0.98)^{\mathrm{b}}$ & $0.94(0.74-1.14)^{\mathrm{b}, \mathrm{c}}$ \\
$15^{\circ} \mathrm{C}$ & & & \\
Female & $1.60(1.43-1.77)^{\mathrm{d}, \mathrm{e}}$ & $2.00(1.76-2.24)^{\mathrm{e}}$ & $1.89(1.71-2.07)^{\mathrm{e}}$ \\
Male & $1.11(0.99-1.23)^{\mathrm{c}}$ & $1.28(1.18-1.38)^{\mathrm{c}, \mathrm{d}}$ & $1.27(1.17-1.37)^{\mathrm{c}, \mathrm{d}}$ \\
Juvenile & $0.86(0.73-0.99)^{\mathrm{b}}$ & $1.05(0.89-1.21)^{\mathrm{b}}$ & $1.23(1.03-1.43)^{\mathrm{c}, \mathrm{d}}$ \\
$20^{\circ} \mathrm{C}$ & & & \\
Female & & & $3.26(2.97-3.55)^{\mathrm{g}}$ \\
Male & $2.67(2.43-2.91)^{\mathrm{f}}$ & $3.21(2.93-3.49)^{\mathrm{g}}$ & $3.19(2.91-3.47)^{\mathrm{g}}$ \\
Juvenile & $2.14(1.95-2.33)^{\mathrm{e}}$ & $2.87(2.62-3.12)^{\mathrm{f}, \mathrm{g}}$ & $1.91(1.74-2.08)^{\mathrm{e}}$ \\
\hline
\end{tabular}

stant at about $1.3 \mathrm{mg} / \mathrm{L}$ regardless of temperature (Table 4). $Q_{10}$ (fractional increase scaled to $10^{\circ} \mathrm{C}$ temperature change) of $\mathrm{MO}_{2}$ was 2.15 (10$\left.15^{\circ} \mathrm{C}\right), 1.64\left(15-20^{\circ} \mathrm{C}\right)$, and $1.88\left(10-20^{\circ} \mathrm{C}\right)$. Although ANCOVA did not reveal significant effect of sex on $\mathrm{MO}_{2}$ before mass-correction ( $p=$ 0.119), mass-corrected $\dot{\mathrm{MO}}_{2}$ was significantly higher in females than in males at $10^{\circ} \mathrm{C}(p<$ 0.01 ). $\mathrm{MO}_{2}$ of females did not differ significantly. from males at 15 and $20^{\circ} \mathrm{C}$.

\section{Mate-guarding behavior}

Hypoxia significantly inhibited the reunion of separated amplexing pairs (ANOVA $p<0.0001$, Fig. 2). About $70 \%$ of separated pairs reunited within $15 \mathrm{~min}$ in normoxia whereas only $25 \%$ of pairs reunited at $4 \mathrm{ppm}$. At $2 \mathrm{ppm}$, no pairs reunited. The slope of the relationship in the mid-range of hypoxia was steep: at 5 ppm about twice as many pairs reunited as at $4 \mathrm{ppm}$ (Fig. 2). The highest $D O$ showing significant adverse effect was $5 \mathrm{ppm}$. Tukey comparisons among DO levels were significant $(p<0.05)$ except $3-$ 4, 4-5, 5-7, and 7-10 ppm.

Prolonged hypoxia induced separation of pairs (Fig. 3). At 9 ppm, over $60 \%$ of the animals remained paired after $48 \mathrm{~h}$ whereas only about $30 \%$ remained paired at $2.5 \mathrm{ppm}$. Differences among DO levels were insignificant at $24 \mathrm{~h}$ (ANOVA $p=0.074$ ) but significant at $48 \mathrm{~h}(p=$ $0.003)$ and 72 hours $(p=0.016)$. Variability was high and only the lowest DO tested (2 ppm) gave results that differed significantly from the control (Tukey, $p<0.05$ ).

\section{Discussion}

Although many aquatic invertebrates are able to survive prolonged anoxia (Bryant 1991), this ability is poorly developed in G. pseudolimnaeus. Sprague (1963) found that $\mathrm{LT}_{50}$ for adult G. pseudolimnaeus was about $1 \mathrm{~h}$ at $20^{\circ} \mathrm{C}$ and $2-3 \mathrm{~h}$ at $10^{\circ} \mathrm{C}$ in nearly deoxygenated water. Results of

TABLE 3. Highest tested levels of dissolved oxygen ( $\mathrm{ppm}$ ) resulting in significant mortality over 3 exposure periods at 3 temperatures.

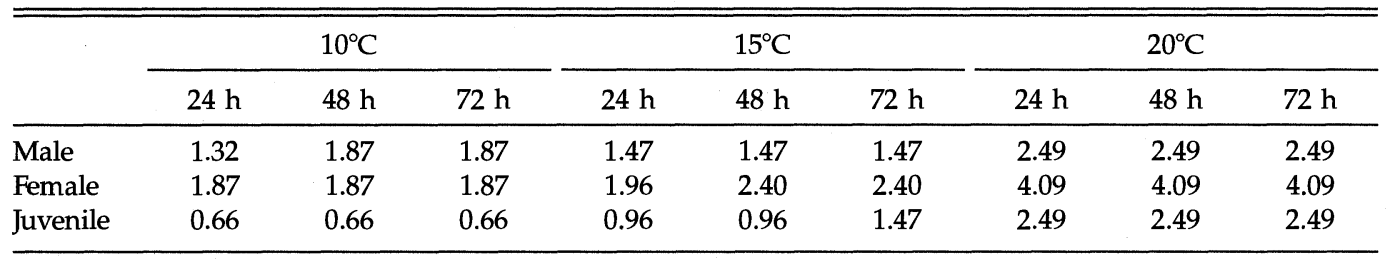




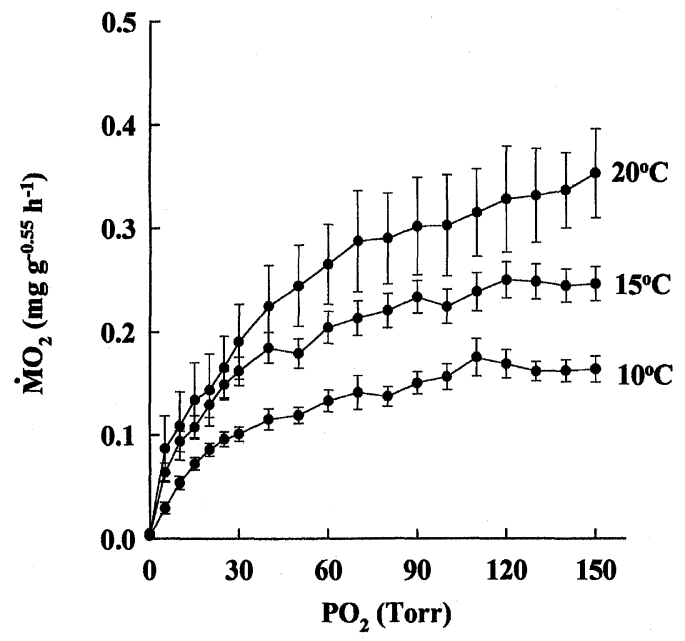

FIG. 1. Mass-corrected rate of oxygen consumption of adult Gammarus pseudolimnaeus (mean $\pm 95 \% \mathrm{CI}$ ) vs. partial pressure of dissolved oxygen at 10,15 , and $20^{\circ} \mathrm{C}$. $n=12,28$, and 12 individuals measured at 10 , 15 , and $20^{\circ} \mathrm{C}$, respectively. Results from both sexes were pooled.

our study are similar (Table 1). Other species of Gammarus may be more tolerant of anoxia; $\mathrm{LT}_{50}$ of G. fossarum was $6.3 \mathrm{~h}$ at $11^{\circ} \mathrm{C}$ (Hervant and Mathieu 1995).

Lethal levels of hypoxia differ among Gammarus species: at $20^{\circ} \mathrm{C}, 24 \mathrm{~h} \mathrm{LC}_{50}$ was $3.0 \mathrm{ppm}$ for G. limnaeus (Gaufin 1973), $4.3 \mathrm{ppm}$ for G. fasciatus, and $2.2 \mathrm{ppm}$ for G. pseudolimnaeus (Sprague 1963). The latter result was similar to those in this study $\left(20^{\circ} \mathrm{C}, 24 \mathrm{~h}\right.$, female $2.7 \mathrm{ppm}$, male $2.1 \mathrm{ppm}$, Table 2). In contrast, $\mathrm{LC}_{50}$ of $\mathrm{G}$. lacturus was $0.4-0.6 \mathrm{ppm}$ for $7 \mathrm{~d}$ exposure at

TABLE 4. Oxygen-dependence of oxygen consumption of Gammarus pseudolimnaeus at 3 temperatures. $\mathrm{MO}_{2}\left(\mathrm{mg} \cdot \mathrm{g}^{-0.55} \cdot \mathrm{h}^{-1}\right)$ can be predicted from DO as follows: $\mathrm{MO}_{2}=\mathrm{DO} \times[\mathrm{a}+\mathrm{bDO}]^{-1}$. HSC is the "half saturation concentration"- the DO at which $\mathrm{MO}_{2}$ is reduced by half (Sutcliffe 1984).

\begin{tabular}{clrrr}
\hline \hline $\begin{array}{c}\text { Temper- } \\
\text { ature }\end{array}$ & $\begin{array}{c}\text { DO } \\
\text { units }\end{array}$ & \multicolumn{1}{c}{$\mathrm{a}$} & $\mathrm{b}$ & HSC \\
\hline $10^{\circ} \mathrm{C}$ & Torr & 108.8414 & 5.1216 & 16.3 \\
& $\mathrm{mg} / \mathrm{L}$ & 9.5490 & 4.9274 & 1.4 \\
$15^{\circ} \mathrm{C}$ & Torr & 68.1547 & 3.6097 & 17.5 \\
& $\mathrm{mg} / \mathrm{L}$ & 5.3696 & 3.4881 & 1.2 \\
$20^{\circ} \mathrm{C}$ & Torr & 77.3579 & 2.4275 & 22.2 \\
& $\mathrm{mg} / \mathrm{L}$ & 4.6896 & 2.4274 & 1.3 \\
\hline
\end{tabular}

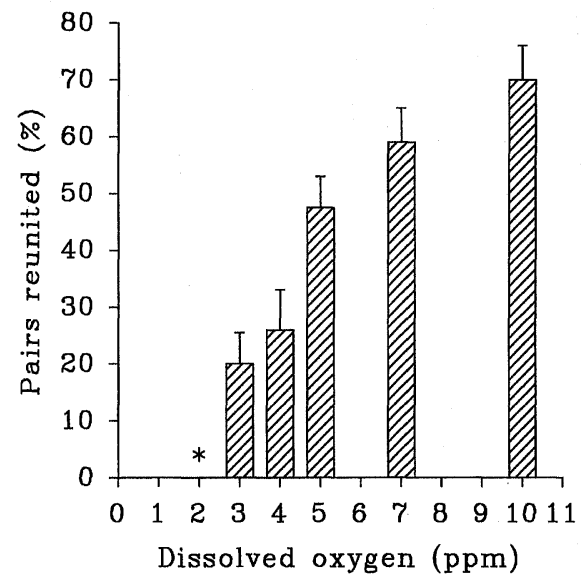

FIG. 2. Mean percent ( $\pm 95 \% \mathrm{CI})$ of separated amplexing pairs reunited within $15 \mathrm{~min}$ vs. dissolved oxygen $\left(15^{\circ} \mathrm{C}\right) . n=50$ at each level of DO. *No pairs reunited at $2 \mathrm{ppm}$.

$13^{\circ} \mathrm{C}$ (Nebeker et al. 1992). Greater tolerance of hypoxia is consistent with the fact that G. lacturus is typically found in large, slow-flowing, turbid, and seasonally warm rivers (Bousfield 1958). Access to the air-water interface lowered $\mathrm{LC}_{50}$ of G. lacturus (Nebeker et al. 1992). However, in lotic environments, surfacing may expose animals to downstream drift and predation (Kolar and Rahel 1993). Acclimation to higher temperatures may also increase hypoxia tolerance: G. pseudolimnaeus acclimated to $20^{\circ} \mathrm{C}$ had lower $24 \mathrm{~h} \mathrm{LC}_{50}$ at $20^{\circ} \mathrm{C}$ than those acclimated to $10^{\circ} \mathrm{C}$ (Sprague 1963).

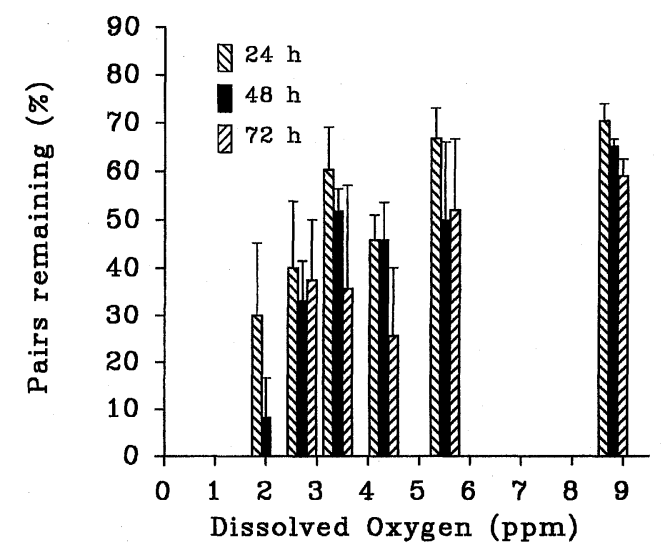

FIG. 3. Mean percent $( \pm 95 \%$ CI) of pairs remaining in amplexus after 24,48 , and $72 \mathrm{~h}$ vs. dissolved oxygen $\left(15^{\circ} \mathrm{C}\right) . n=36$ possible pairs at each level of DO. 
TABLE 5. Relationships between $\mathrm{MO}_{2}$, body mass, and temperature in Gammarus species (sexes pooled). Regressions of $\log \mathrm{MO}_{2}(\mu \mathrm{g} / \mathrm{h})$ vs. log dry body mass (mg): $\log \dot{M O}_{2}=\log a+b\left(\log\right.$ Mass). $\mathbf{M}_{10}$ is predicted $\dot{\mathrm{MO}}_{2}(\mu \mathrm{g} / \mathrm{h})$ for an individual of $10 \mathrm{mg}$ dry mass.

\begin{tabular}{lccccc}
\hline \multicolumn{1}{c}{ Species } & $\left({ }^{\circ} \mathrm{C}\right)$ & $\log \mathrm{a}$ & $\mathrm{b}$ & $\mathrm{M}_{10}$ & Source $^{\mathrm{a}}$ \\
\hline G. pulex & 10 & 1.157 & 0.756 & 81.8 & 1 \\
& 10 & 0.394 & 0.849 & 71.5 & 2 \\
& 15 & 0.469 & 0.930 & 25.1 & 2 \\
& 20 & 1.555 & 0.699 & 179.5 & 1 \\
G. fossarum & 12 & 0.083 & 0.75 & 6.81 & 3 \\
& 12 & 0.1 & 0.734 & 6.82 & 4 \\
G. pseudolimnaeus & 10 & 0.279 & 0.701 & 9.55 & 4 \\
& 15 & 0.077 & 1.19 & 12.97 & 5 \\
& 20 & 0.535 & 0.782 & 20.18 & 5 \\
& & & & \\
& 16.28 .2 & 5 \\
\hline
\end{tabular}

a 1) Rumpus and Kennedy 1974, 2) Nilsson 1974, 3) Franke 1977, 4) Pieper 1978 (1-4 cited by Sutcliffe 1984) 5) present study

Differences in hypoxia tolerance among sexes and ages might result from differences in oxygen transport capability. The smaller juvenile amphipods were more tolerant of hypoxia than were the larger adults. Assuming that cutaneous gas exchange is significant, small individuals may be better able to take up oxygen at low oxygen tensions, because small animals have a higher surface-to-volume ratio. A second possibility is that juveniles are better able to supplement energy demands by anaerobic metabolism. This hypothesis is falsified, however, by the fact that juveniles did not die more slowly than adults in anoxia (Table 1). Smaller individuals have higher mass-specific metabolic rate, as indicated by mass exponents less than 1.0 (Table 5). Higher energy demand, lower energy reserves, or both, might contribute to a shortfall between energy demands and supply by anaerobic glycolysis and explain the quicker death of juveniles in anoxia.

Females are smaller than males; thus they were expected to be less susceptible to hypoxia than males. In fact, $\mathrm{LC}_{50}$ for the females was higher than that for the larger males, and adult females also died more quickly than males in anoxia. The greater sensitivity of female amphipods to hypoxia is unexplained. Females brood the developing embryos in a ventral pouch formed by the setae of the oostegites (SainteMarie 1991). The brood pouch is adjacent to the female's gills and could interfere with ventilation (Sutcliffe 1984) or reduce DO near the female's gills. Interestingly, juvenile amphipods that are old enough to swim leave the brood pouch when DO drops to $3.5 \mathrm{ppm}$ at $15^{\circ} \mathrm{C}$ (C. Barnhart, unpublished observations). Quicker death of the females during anoxia also suggests that females are less able to meet energy needs anaerobically, perhaps because of higher energy demand, lower energy reserves, or both.

\section{Oxygen consumption}

The magnitude of $\mathrm{MO}_{2}$ of G. pseudolimnaeus found in this study is within the range reported for other Gammarus species (Table 5). Rees (1972) reported $\mathrm{MO}_{2}$ of G. pseudolimnaeus ranging from $0.65-1.5 \mathrm{mg} \cdot \mathrm{g}^{-1} \cdot \mathrm{h}^{-1}$ in air-saturated water at $10^{\circ} \mathrm{C}$. Assuming a typical $10 \mathrm{mg}$ dry mass, our result $\left(1.3 \mathrm{mg} \cdot \mathrm{g}^{-1} \cdot \mathrm{h}^{-1}\right)$ is within this range. DO dependence of $\mathrm{MO}_{2}$ of G. pseudolimnaeus was less marked than has been reported for other Gammarus species (reviewed by Sutcliffe 1984). The $\mathrm{PO}_{2}$ at which $\mathrm{MO}_{2}$ was reduced by half from that at air saturation was 16-22 Torr (Table 4) versus averages of 38 Torr for $G$. pulex and 36 Torr for G. fossarum (Sutcliffe 1984). DO dependence of $\mathrm{MO}_{2}$ may be sensitive to convection. Rees (1972) found $\mathrm{MO}_{2}$ of G. pseudolimnaeus in unstirred respirometers was halved at 60 Torr $(4.5 \mathrm{ppm})$ at $10^{\circ} \mathrm{C}$, more than twice as high as our result.

Respiration of Gammarus shows a curvilinear response to DO with no distinct "critical" level (reviewed by Sutcliffe 1984). Thus, any degree of environmental hypoxia may affect respiration. At 4 ppm, the minimum DO currently defended downstream from Table Rock Dam, respiration at $15^{\circ} \mathrm{C}$ is reduced by $16.7 \%$ relative to air saturation (10 ppm) (calculation from Table 4). The effects of this metabolic inhibition on growth and development should be investigated. In Hyalella azteca, both adult mass and number of young produced are depressed by hypoxia (Nebeker et al. 1992).

\section{Mate-guarding behavior}

Mate-guarding ensures that the male is present during the short period of female receptivity (Conlan 1991) and protects the female from predatory attack by other amphipods (Dick and Elwood 1989). Mate-guarding is affected by 
temperature (Hartnoll and Smith 1980), pH (McCahon and Poulton 1991), predator presence (Strong 1973), and pollutants (Malbouisson et al. 1994), and can be used as a sensitive indicator of sub-lethal stress (Poulton and Pascoe 1990). Hypoxia inhibited mate-guarding in a field study of G. pulex; some pairs separated at $8 \mathrm{ppm}$ and $55 \%$ of pairs separated at $1 \mathrm{ppm}(24$ $\mathrm{h}, 15^{\circ} \mathrm{C}$ ) (McCahon et al. 1991). In our study, more than half of amplexed individuals separated at $2 \mathrm{ppm}\left(24 \mathrm{~h}, 15^{\circ} \mathrm{C}\right)$ (Fig. 3). The reunion of separated pairs was significantly inhibited at 5 ppm (Fig. 2). The cause of these effects has not been investigated. Because the female is carried near the male's pleopods and gills, amplexus may limit the male's ability to ventilate.

\section{Hypoxia and drift}

Another potentially critical effect of hypoxia on amphipods is stimulation of emergence from benthic refugia and resulting exposure to predation and downstream drift. Gammarus lacustris emerged from benthic refugia as DO decreased below $4.5 \mathrm{ppm}$ at $4^{\circ} \mathrm{C}$ (Kolar and Rahel 1993). Moderate hypoxia promotes positive rheotaxis in Gammarus, but sublethal and lethal levels of DO induce negative rheotaxis; the peak of positive rheotaxis occurs at lower DO in hypoxia-tolerant species and ranged from $2.7 \mathrm{mg} /$ $\mathrm{L}$ in G. pulex to $5.3 \mathrm{mg} / \mathrm{L}$ in G. fossarum at $15^{\circ} \mathrm{C}$ (Vobis 1973).

\section{Water quality criteria}

The results suggest that all categories of $G$. pseudolimnaeus tested would survive $72 \mathrm{~h}$ at the $4 \mathrm{ppm}$ minimum that is currently defended in the tailwater of Table Rock Dam. However, DO occasionally falls below $3 \mathrm{ppm}$ during periods of reduced power generation when oxygenation procedures at the dam are ineffective (Hoback 1995). In such situations, mortality of adult females may occur. Significant sublethal effects of hypoxia on respiration and reproductive behavior are evident at much higher levels of DO. Metabolic depression by low DO may adversely affect growth of aquatic organisms (Alabaster and Lloyd 1980). We suggest that appropriate criteria for DO for Gammarus pseudolimnaeus would allow no more than $10 \%$ depression of respiration and no inhibition of reproductive behavior.

Although the acute lethal DO for salmonids is approximately $3 \mathrm{ppm}$ (Alabaster and Lloyd 1980), US Environmental Protection Agency (EPA) criteria for DO in coldwater fisheries are higher, in recognition of the higher DO sensitivity of some invertebrates (US EPA 1986). DO standards vary among states in the US and among bodies of water within states (US EPA 1988). The US EPA criterion for 7-d mean DO and 7-d mean daily minimum DO (6.5 and 5.0 ppm, respectively) and the existing Missouri state standard for minimum DO in coldwater fisheries $(6 \mathrm{ppm})$ appear to be consistent with the survival and unimpaired function of Gammarus pseudolimnaeus. Such standards, however, may often be unmet below hypolimnetic-release hydropower dams.

\section{Acknowledgements}

We thank Mike Kruse, Gordon Proctor, John Havel, Tom Tomasi, Alicia Mathis, Mitch Henson, and Andy Roberts for their generous contributions of time and expertise. This project was supported by the Missouri Department of Conservation, Fisheries Research Division and by the Department of Biology, Southwest Missouri State University.

\section{Literature Cited}

AlABASTER, J. S., AND R. LloYD. 1980. Dissolved oxygen. Pages 127-143 in J. S. Alabaster and R. Lloyd (editors). Water quality criteria for freshwater fish. Butterworth's, London.

BARNHART, M. C. 1995. An improved gas-stripping column for deoxygenating water. Journal of the North American Benthological Society 14:347350.

BAYNE, B. L. 1971. Oxygen consumption by three species of lamellibranch mollusc in declining oxygen tension. Comparative Biochemistry and Physiology 40A:955-970.

BOUSFIELD, E. L. 1958. Fresh-water amphipod crustaceans of glaciated North America. The Canadian Field Naturalist 72:55-113.

BRYANT, C. 1991. Metazoan life without oxygen. Chapman and Hall, London.

CONLAN, K. E. 1991. Precopulatory behavior and sexual dimorphism in the amphipod Crustacea. Hydrobiologia 223:255-282.

DiCK, J. T. A., AND R. W. ElwOOD. 1989. Assessments and decisions during mate-choice in Gammarus pulex (Amphipoda). Behavior 109:225-246.

FRANKE, U. 1977. Experimentelle Untersuchungen zur 
Respiration von Gammarus fossarum Koch 1835 (Crustacea, Amphipoda). Experientia 25:539-540.

GAUFIN, A. R. 1973. Water quality requirements of aquatic insects. EPA 660/3-73-004. United States Environmental Protection Agency, Corvallis, Oregon.

HANSON, D. L., AND T. F. WATERS. 1974. Recovery of standing crop and production rate of a brook trout population in a flood-damaged stream. Transactions of the North American Fisheries Society 103:431-439.

HARTNOlL, R. G., ÁND S. M. SMith. 1980. An experimental study of sex discrimination and pair formation in Gammarus duebeni (Amphipoda). Crustaceana 38:253-264.

Hervant, F., AND J. MATHIEU. 1995. Ventilatory and locomotory activities in anoxia and subsequent recovery of epigean and hypogean crustaceans. Comptes Rendus de 1'Academie des Sciences Paris, Sciences de la vie 318:585-592.

НовАСК, W. W. 1995. Hypoxia-limited survival, respiration, and mate-guarding behavior in the am phipod Gammarus pseudolimnaeus Bousfield. Master's thesis, Southwest Missouri State University, Springfield.

KAUFMANN, R., H. FORSTNER, AND W. WEISER. 1989. Respirometery-methods and approaches. Pages 51-76 in C. R. Bridges and P. J. Butler (editors). Techniques in comparative respiratory physiology. Cambridge University Press, Cambridge, UK.

KOLAR, C. S., AND F. J. RAHEL. 1993. Interaction of a biotic factor (predator presence) and an abiotic factor (low oxygen) as an influence on benthic invertebrate communities. Oecologia 95:210-219.

Malbouisson, J. F. C., T. W. K. YounG, AND A. W. BARK. 1994. Disruption of precopula in Gammarus pulex as a result of brief exposure to gammahexachlorinecyclohexane (lindane). Chemosphere 28:2011-2020.

MARCHANT, R., AND H. B. N. HYNES. 1981. The distribution and production of Gammarus pseudolimnaeus (Crustacea, Amphipoda) in the Credit Riv $\rightarrow$ er, Ontario. Freshwater Biology 11:169-182.

MCCAHON, C. P., AND M. J. POULTON. 1991. Lethal and sub-lethal effects of acid, aluminum and lime on Gammarus pulex during repeated simulated episodes in a Welsh stream. Freshwater Biology 25: 169-178.

MCCAhON, C. P., M. J. Poulton, P. C. Thomas, Q. XU, D. PASCOE, AND C. TuRner. 1991. Lethal and sub-lethal toxicity of field simulated farm waste episodes to several freshwater invertebrate species. Water Research 25:661-671.

MEIJERING, M. P. D. 1991. Lack of oxygen and low $\mathrm{pH}$ as limiting factors for Gammarus in Hessian brooks and rivers. Hydrobiologia 223:159-169.

NebeKer, A. V., S. T. OnJuKKA, D. G. STevens, G. A.
ChAPMAN, AND S. J. DomingueZ. 1992. Effects of low dissolved oxygen on survival, growth, and reproduction of Daphnia, Hylalella, and Gammarus. Environmental Toxicology and Chemistry 11:373379.

NILSSON, L. M. 1974. Energy budget of a laboratory population of Gammarus pulex (Amphipoda). Oikos 25:35-42.

PenNaK, R. W. 1989. Amphipoda (scuds, sideswimmers). Pages 474-478 in Fresh-water invertebrates of the United States. 3rd edition. John Wiley and Sons, New York.

PIEPER, H. G. 1978. Okophysiologische und produktionsbiologische Untersuchenungen an Jungstadien von Gammarus fossarum Koch 1835. Archiv für Hydrobiologie, Supplementband 54:257-327.

POUlTON, M., AND D. PASCOE. 1990. Disruption of precopula in Gammarus pulex (L.)-development of a behavioural bioassay for evaluating pollutant and parasite induced stress. Chemosphere 20: 403-415.

REES, C. P. 1972. The distribution of the amphipod Gammarus pseudolimnaeus Bousfield as influenced by oxygen concentration, substratum, and current velocity. Transactions of the North American Microscopical Society 91:514-529.

RuMPUS, A. E., AND C. R. KENNEDY. 1974. The effect of acanthocephalan Pomphorynchus laevis upon the respiration of its intermediate host Gammarus pulex L. Parasitology 68:271-284.

SAINTE-MARIE, B. 1991. A review of the reproductive bionomics of aquatic gammaridian amphipods: variation in life history traits with latitude, depth, salinity, and superfamily. Hydrobiologia 233:189227.

SCHMIDT-NIELSON, K. 1984. Scaling: why is animal size so important? Cambridge University Press, New York.

SPRAGUE, J. B. 1963. Resistance of four freshwater crustaceans to lethal high temperature and low oxygen. Journal of the Fisheries Research Board of Canada 20:388-415.

StRONG, D. R. 1973. Amphipod amplexus, the significance of ecotypic variation. Ecology 54:13831388.

SUTCLIFFE, D. W. 1984. Quantitative aspects of oxygen uptake by Gammarus (Crustacea, Amphipoda): a critical review. Freshwater Biology 14:443-489.

TANG, P. S. 1933. Oxygen consumption as a function of oxygen pressure. Quarterly Review of Biology $8: 260-274$.

US EPA (UNITED STATES ENVIRONMENTAL PROTECTION AGENCY). 1986. Ambient water quality criteria for dissolved oxygen. EPA 440/5-86-003. United States Environmental Protection Agency, Washington, D.C.

US EPA (UNITED STATES ENVIRONMENTAL PROTECTION AGENCY). 1988. Dissolved oxygen water quality 
standards criteria summaries: a compilation of state/federal criteria. EPA 440/5-88/024. United States Environmental Protection Agency, Washington, D.C.

VOBIS, H. 1973. Rheotaktisches verhalten einiger Gammarus-Arten bei verschiedenem Sauerstoffgehalt des Wassers. Helgoländer wissenschaftliche Meeresuntersuchungen 25:495-508.

WALlaCE, R. R., H. B. N. HYNES, AND N. K. KAUSHIK. 1975. Laboratory experiments on factors affecting the activity of Gammarus pseudolimnaeus Bousfield. Freshwater Biology 5:533-546.

WATERS, T. F., AND J. C. HOKENSTROM. 1980. Annual production and drift of the stream amphipod Gammarus pseudolimnaeus in Valley Creek, Minnesota. Limnology and Oceanography 24:700710.

WeItHMAN, A. S., AND M. A. HAAS. 1984. Effects of dissolved oxygen depletion on the rainbow trout fishery in Lake Taneycomo, Missouri. Transactions of the American Fisheries Society 111:223230.

ZAR, J. H. 1984. Biological statistics. 2nd edition. Prentice-Hall, Englewood Cliffs, New Jersey.

Received: 21 June 1995

Accepted: 6 December 1995 